\title{
The spider family Oecobiidae (Arachnida: Araneae) in Iran, Afghanistan and Turkmenistan
}

\author{
Alireza ZAMANI ${ }^{1, *} \&$ Jan BOSSELAERS ${ }^{2}$ \\ ${ }^{1}$ Zoological Museum, Biodiversity Unit, FI-20014 University of Turku, Finland. \\ ${ }^{2}$ Royal Museum for Central Africa, B 3080 Tervuren, Belgium. \\ *Corresponding author: zamani.alireza5@gmail.com \\ 2Email: dochterland@telenet.be \\ ${ }^{1}$ urn:1sid:zoobank.org:author:A21C0B82-E2D9-4402-9408-D6160843DAF4 \\ ${ }^{2}$ urn:lsid:zoobank.org:author:D6AD7414-3540-4F06-8631-8873450AA90C
}

\begin{abstract}
The taxonomic and faunistic status of the spider family Oecobiidae in Iran, Afghanistan and Turkmenistan is revised. A new species, namely Uroctea gambronica sp. nov. ( $\overbrace{}^{\Uparrow})$ is described from southern Iran, and the male of U. grossa Roewer, 1960 is described and illustrated for the first time. Additionally, new faunistic data are provided, including the first records of Oecobius putus O. PickardCambridge, 1876 and $U$. grossa in Afghanistan and Turkmenistan, respectively, and the re-evaluation of previously misidentified and questionable records of this family in the region. The known distribution ranges of all species are mapped for these three countries.
\end{abstract}

Keywords. Central Asia, new combination, new species, tent-web spiders.

Zamani A. \& Bosselaers J. 2020. The spider family Oecobiidae (Arachnida: Araneae) in Iran, Afghanistan and Turkmenistan. European Journal of Taxonomy 726: 38-58. https://doi.org/10.5852/ejt.2020.726.1173

\section{Introduction}

The spider family Oecobiidae Blackwall, 1862 is globally represented by 119 extant species in six genera, two of which occur in the Palaearctic: Oecobius Lucas, 1846 and Uroctea Dufour, 1820 (World Spider Catalog 2020). The latter genus was formerly classified as the sole member of the family Urocteidae Thorell, 1869 until Lehtinen (1967) moved it into Oecobiidae, as the single representative of the ecribellate subfamily Urocteinae Thorell, 1869. Two other subfamilies include the cribellate Oecobiinae Blackwall, 1862 and the ecribellate Uroecobiinae Kullmann \& Zimmermann, 1976 (Yang et al. 2019). In the Middle East and Central Asia, the family has been relatively poorly studied. In his taxonomic and biogeographic revision of the species of Oecobius occurring in the Mediterranean Region and the Arabian Peninsula, Wunderlich (1995) described several new species and provided many new distribution records of the genus. Also, country level revisions have been provided for Egypt (Hassan 1953), Iran (Zamani et al. 2017a) and Turkey (Demir et al. 2009), and more scattered contributions have been made by Zamani et al. (2016), El-Hennawy (2016), Zamani \& Marusik (2018) and Boukan et al. (2018). The genus Uroctea has received far less attention in the region, with few revisionary works 
provided for Yemen (Rheims et al. 2007) and Turkey (Kunt et al. 2009), and scattered descriptions and records published by Roewer (1960), Zamani et al. (2015) and Fomichev \& Marusik (2020). In this paper, we aim to revise the status of this family in Iran, Afghanistan and Turkmenistan, based on museum material and other recently collected specimens.

\section{Material and methods}

Specimens were studied using a Euromex MIC465 and an Olympus SZX9 stereo microscopes. Illustrations of internal genitalia were made after digestion of soft tissues in trypsin (Sigma) for 24 hours at room temperature and clearing in methyl salicylate. Lengths of leg segments were measured on the dorsal side. Leg spination is illustrated in a schematic representation where prolateral, dorsal, retrolateral and ventral sides of leg articles are flattened as a folding net (Dürer 1525). Measurements of legs are listed as: total length (femur, patella, tibia, metatarsus, tarsus). All measurements are given in millimeters. The maps (Figs 1-2) were created using the webpage SimpleMappr (online at http://www.simplemappr.net/). Geographic coordinates, if not available from the labels, were georeferenced using Google Earth (online at https://www.google.com/earth/).

\section{Abbreviations}

\section{Carapace}

$\mathrm{PSP}=$ plagula sternalis postica (the plagula is a triangular or ribbon-shaped sclerite situated on the ventral side of the petiolus; it may be fused with the sternum, see Simon 1892: 5, figs. 15-18; Ledoux \& Canard 1991: figs. 13-14)

\section{Eyes}

$$
\begin{aligned}
\text { AER } & =\text { anterior eye row } \\
\text { ALE } & =\text { anterior lateral eyes } \\
\mathrm{AME} & =\text { anterior median eyes } \\
\mathrm{MOQ} & =\text { median ocular quadrangle } \\
\mathrm{PER} & =\text { posterior eye row } \\
\mathrm{PLE} & =\text { posterior lateral eyes } \\
\mathrm{PME} & =\text { posterior median eyes }
\end{aligned}
$$

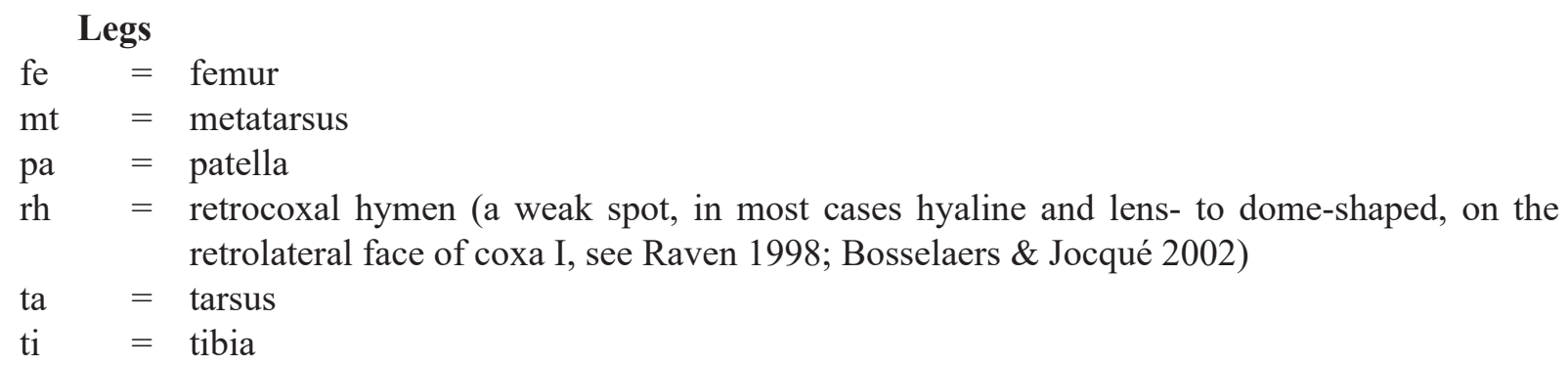

\section{Spinnerets}

ALS $=$ anterior lateral spinnerets

PLS = posterior lateral spinnerets

PMS $=$ posterior median spinnerets

$$
\begin{aligned}
& \multicolumn{2}{c}{\text { Male copulatory organs }} \\
& \mathrm{C}=\text { conductor } \\
& \mathrm{E} \quad=\text { embolus } \\
& \mathrm{fC} \quad=\text { functional conductor } \\
& \mathrm{MA}=\text { median apophysis }
\end{aligned}
$$


MAb1 $=$ median apophysis, branch 1

MAb2 $=$ median apophysis, branch 2

MAb3 = median apophysis, branch 3

OEA $=$ oecobiid embolic apophysis

OTA $=$ oecobiid tegular apophysis

OTL = oecobiid tegular lobe

$\mathrm{Ra}=$ radix

$\mathrm{RaA}=$ radix apophysis

$\mathrm{S}=$ stipes

STA $=$ subterminal apophysis

$\mathrm{T}=$ tegulum

$\mathrm{TA}=$ terminal apophysis

$\mathrm{TL}=$ tegular lobe

\section{Female copulatory organs}

$\mathrm{Bd}=$ blind ending $\operatorname{duct}(\mathrm{s})$

$\mathrm{Bu}=\operatorname{bursa}(\mathrm{e})$

$\mathrm{Cd}=$ copulatory $\operatorname{duct}(\mathrm{s})$

$\mathrm{Co}=$ copulatory opening

$\mathrm{Fd}=$ fertilization $\operatorname{duct}(\mathrm{s})$

St $=$ spermatheca $(\mathrm{e})$

\section{Leg spination}

do $=$ dorsal side

$\mathrm{pl}=$ prolateral side

plv $=$ ventroprolateral side

$\mathrm{rl} \quad=$ retrolateral side

rlv $=$ ventroretrolateral side

ve $=$ ventral side

\section{Repositories}

$\mathrm{CJB}=$ personal collection of Jan Bosselaers

GNM = Göteborgs Naturhistoriska Museum, Göteborg, Sweden

MHNG = Muséum d'Histoire naturelle, Genève, Switzerland

NMP $=$ National Museum in Prague, Czech Republic

RBINS = Royal Belgian Institute of Natural Sciences, Brussels, Belgium

SMF = Senckenberg Research Institute, Frankfurt am Main, Germany

ZMMU $=$ Zoological Museum of Moscow State University, Moscow, Russia

\section{Results}

Class Arachnida Lamarck, 1801

Order Araneae Clerck, 1757

Family Oecobiidae Blackwall, 1862

Genus Oecobius Lucas, 1846

Oecobius cellariorum (Duges, 1836)

Oecobius cellariorum - Ghahari \& Marusik 2009: 4. — Boukan et al. 2018: 24, figs 2a-d (ふ)). 


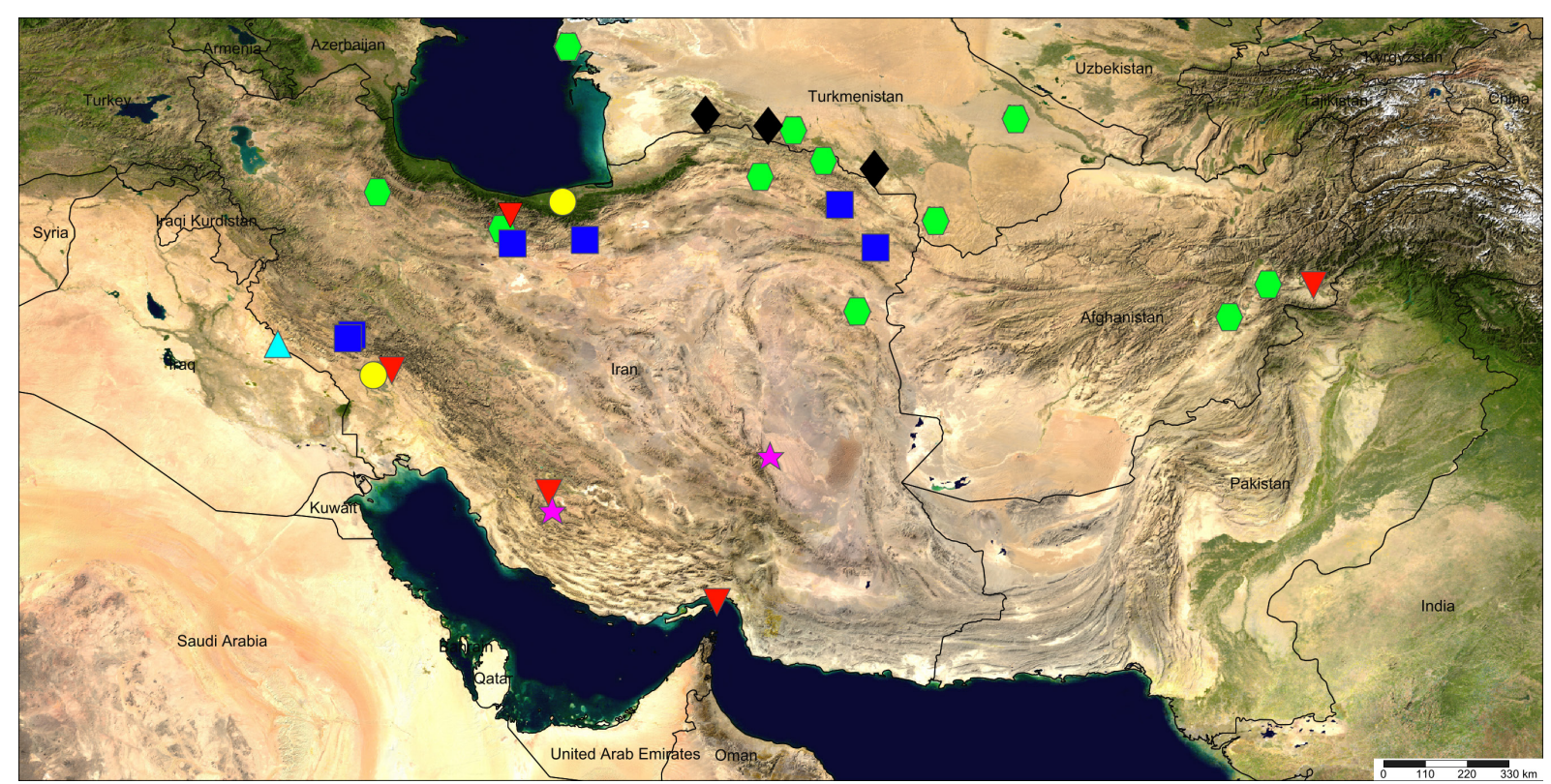

Fig. 1. Distribution of Oecobius Lucas, 1846 in Iran, Afghanistan and Turkmenistan. yellow circles = O. cellariorum (Duges, 1836; pink stars $=$ O. fahimii Zamani \& Marusik, 2018; blue squares $=$ O. ferdowsii Mirshamsi, Zamani \& Marusik, 2017; cyan triangle = O. ilamensis Zamani, Mirshamsi \& Marusik, 2017; green hexagons $=$ O. nadiae (Spassky, 1936); red triangles $=O$. putus O. PickardCambridge, 1876; black diamonds = O. tadzhikus Andreeva \& Tyschchenko, 1969.

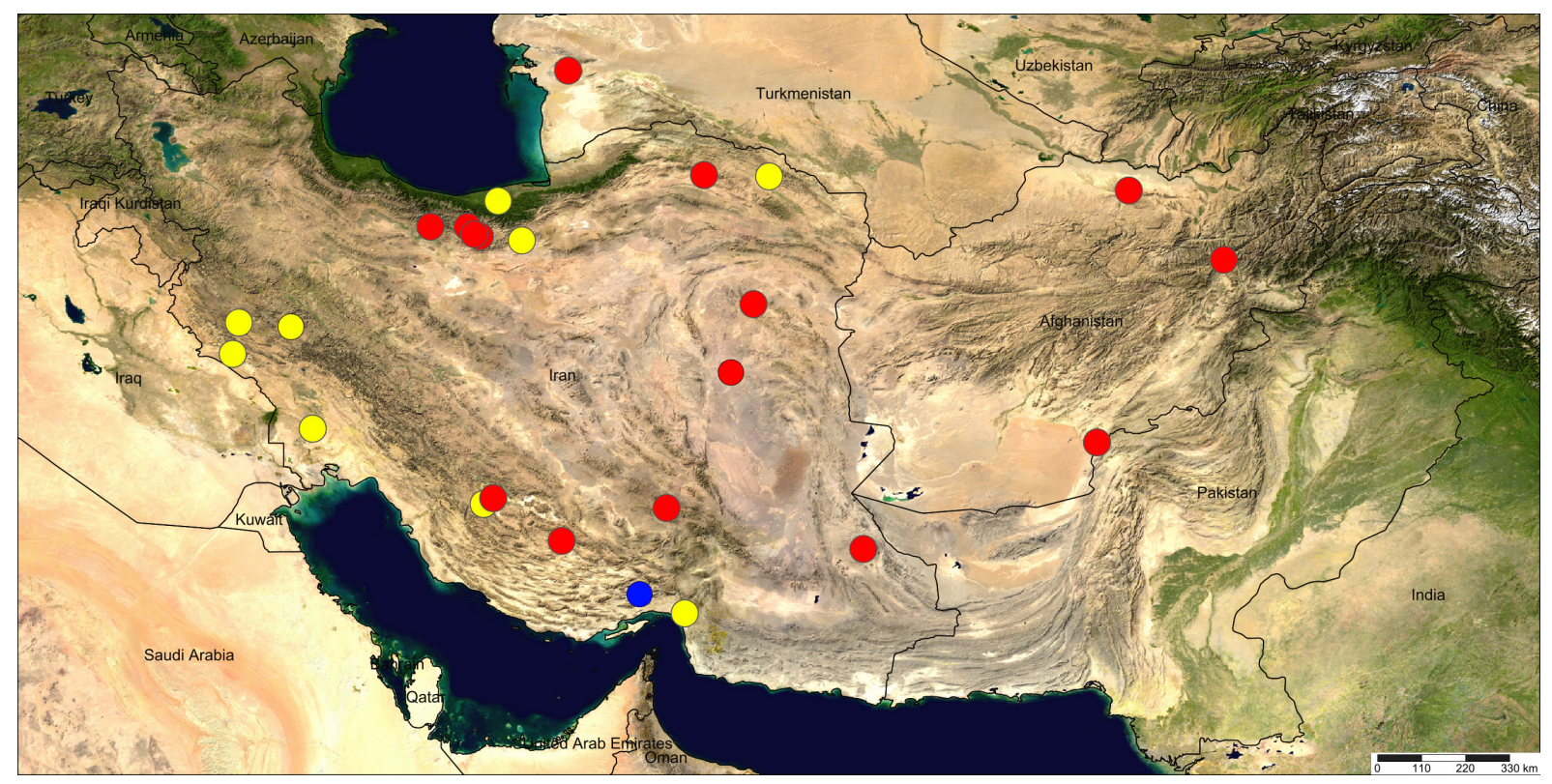

Fig. 2. Distribution of Uroctea Dufour, 1820 in Iran, Afghanistan and Turkmenistan. red circles = U. grossa Roewer, 1960; yellow circles $=U$. thaleri Rheims, Santos \& van Harten, 2007; blue circle = U. gambronica sp. nov. 


\section{Distribution}

Mediterranean Region, Russia (Europe), Azerbaijan, Jordan, Iran. Introduced into USA, China, Japan (World Spider Catalog 2020).

\section{Records in Iran}

Mazandaran (Ghahari \& Marusik 2009) and Khuzestan (Boukan et al. 2018) Provinces (Fig. 1).

Oecobius fahimii Zamani \& Marusik, 2018

Oecobius fahimii Zamani \& Marusik, 2018: 73, figs 2E-F, 3A-E (ㅇ).

\section{Material examined}

IRAN • 1 ㅇ; Fars Province, Kavar; $29^{\circ} 12^{\prime}$ N, 52³7’ E; 5 Jun. 1974; A. Senglet leg.; MHNG.

\section{Distribution}

Iran (World Spider Catalog 2020).

\section{Records in Iran}

Kerman (Zamani \& Marusik 2018) and Fars (this paper) Provinces (Fig. 1).

Oecobius ferdowsii Mirshamsi, Zamani \& Marusik, 2017

Fig. 3A

Oecobius ferdowsii Mirshamsi, Zamani \& Marusik in Zamani et al., 2017a: 333, figs 2A-D, 3A-D (ô, ㅇ).

\section{Distribution}

Iran (World Spider Catalog 2020).

\section{Records in Iran}

Lorestan, Razavi Khorasan, Semnan and Tehran Provinces (Zamani et al. 2017a) (Fig. 1).

Oecobius ilamensis Zamani, Mirshamsi \& Marusik, 2017

Oecobius ilamensis Zamani, Mirshamsi \& Marusik in Zamani et al., 2017a: 331, figs 1A-F (đ)).

\section{Distribution}

Iran (World Spider Catalog 2020).

\section{Records in Iran}

Ilam Province (Zamani et al. 2017a) (Fig. 1).

\section{Oecobius nadiae (Spassky, 1936)}

Fig. 3B

Uroctea nadiae - Denis 1958: 112.

Oecobius afghanicus - Kullmann \& Zimmermann 1976: 42, figs 1-3, 6-9, 12-13 (ô, o + ).

Oecobius nadiae - Mikhailov \& Fet 1994: 503. —Zamani et al. 2015: 342; 2018: 192. — Sadeghi et al. 2016: 6. - Zamani 2016: 82. 

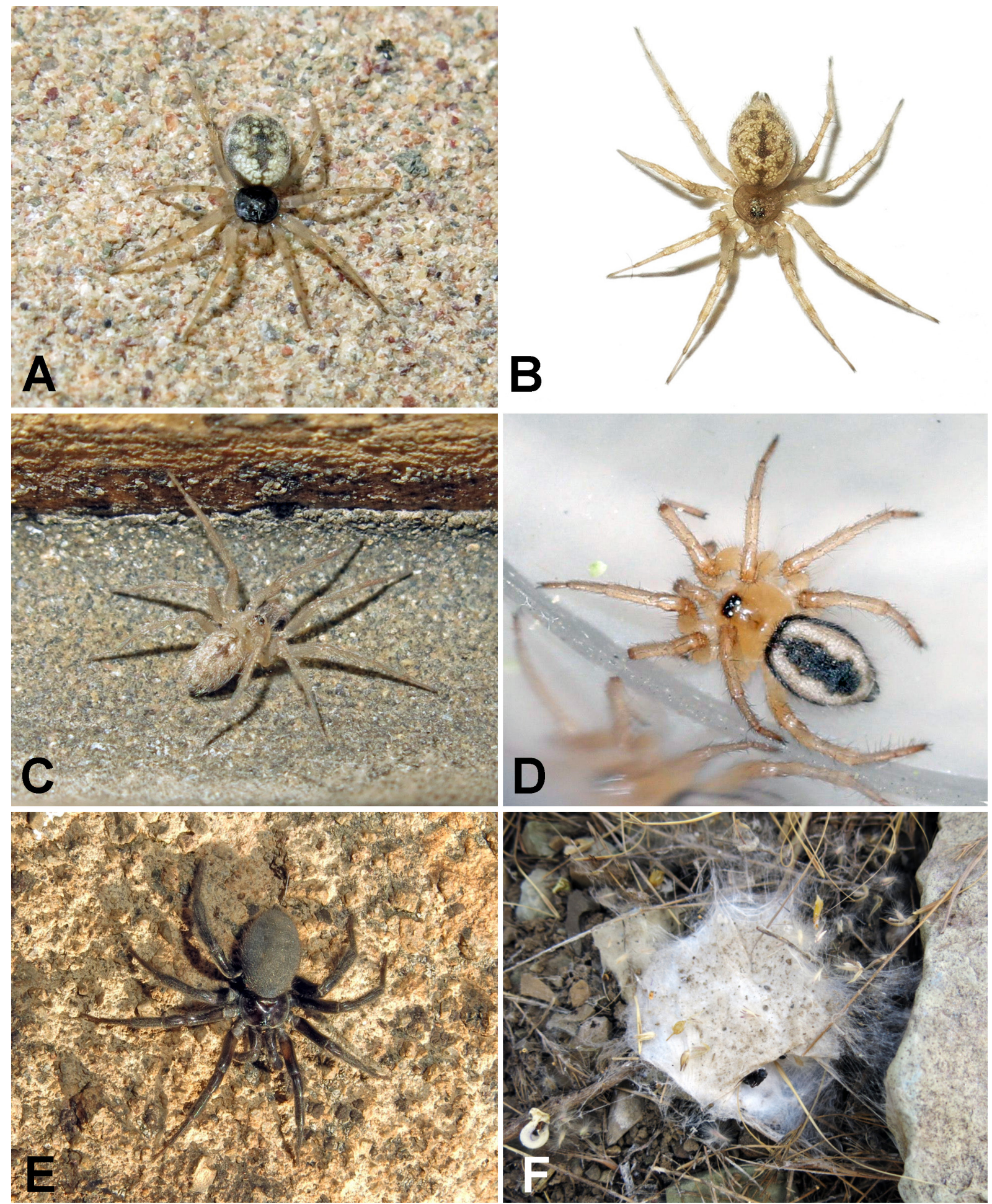

Fig. 3. Live habitus and tent web of oecobiids. A. Oecobius ferdowsii Mirshamsi, Zamani \& Marusik, 2017, ․ . B. Oecobius nadiae (Spassky, 1936), ‥ C. Oecobius putus O. Pickard-Cambridge, 1876, §ొ. D. Uroctea thaleri Rheims, Santos \& van Harten, 2007, juvenile. E. Uroctea grossa Roewer, 1960, . . F. Tent web of Uroctea grossa. A-C, E-F by Alireza Zamani; D courtesy of Mahmoud Kolnegari. 


\section{Material examined}

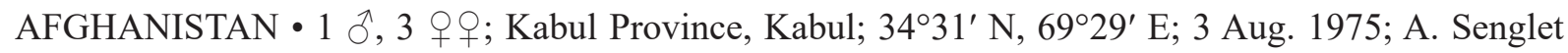

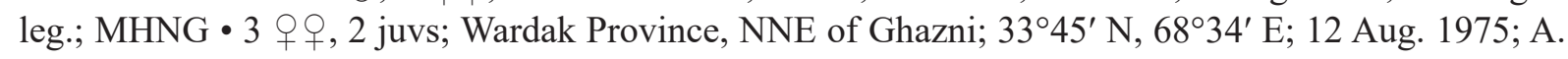
Senglet leg.; MHNG.

\section{Distribution}

Azerbaijan, Iran, Afghanistan, Turkmenistan, Tajikistan, China (World Spider Catalog 2020).

\section{Records in Iran}

North Khorasan, Razavi Khorasan, South Khorasan, Tehran and Zanjan Provinces (Zamani et al. 2015, 2018; Zamani 2016; Sadeghi et al. 2016) (Fig. 1).

\section{Records in Afghanistan}

Kabul (Denis 1958; Kullmann \& Zimmermann 1976; this paper) and Wardak (this paper) Provinces (Fig. 1).

\section{Records in Turkmenistan}

Ahal, Balkan, Mary and Labap Regions (Mikhailov \& Fet 1994) (Fig. 1).

Oecobius putus O. Pickard-Cambridge, 1876

Fig. 3C

Oecobius putus - Zamani 2016: 83. - Zamani et al. 2016: 109, figs 36-40 (ð, ○). — Zamani \& Mozaffarian 2017: 13. — Boukan et al. 2018: 23, figs 3a-d (đ)).

\section{Material examined}

AFGHANISTAN • 1 ô, 6 우; Nangrahar Province, NE of Djelalabad; $34^{\circ} 30^{\prime}$ N, 70³3’ E; 8 Aug. 1975; A. Senglet leg.; MHNG.

IRAN • 1 `̃, 1 क; Mazandaran Province, Pol-e Zanguleh; $36^{\circ} 13^{\prime}$ N, $51^{\circ} 15^{\prime}$ E; 5 Jul. 1975; A. Senglet leg.; MHNG.

\section{Distribution}

Egypt, Sudan to Iran, India. Introduced into USA, Mexico (World Spider Catalog 2020). Newly recorded from Afghanistan.

\section{Records in Iran}

Fars, Hormozgan, Khuzestan, Tehran (Zamani 2016; Zamani et al. 2016; Zamani \& Mozaffarian 2017; Boukan et al. 2018) and Mazandaran (this paper) Provinces (Fig. 1).

\section{Records in Afghanistan}

Nangrahar Province (this paper) (Fig. 1).

Oecobius tadzhikus Andreeva \& Tyschchenko, 1969

Oecobius tadzhikus - Mikhailov \& Fet 1994: 503.

\section{Distribution}

Tajikistan, Turkmenistan (World Spider Catalog 2020). 


\section{Records in Turkmenistan}

Ahal and Balkan Regions (Mikhailov \& Fet 1994). These records have been considered as doubtful and potentially referring to another species by Marusik et al. (2015).

Genus Uroctea Dufour, 1820

Uroctea grossa Roewer, 1960

Figs 3E-F, 4F-G, 5, 6A-D, 7A-C, 8-9

Uroctea grossa Roewer, 1960: 51, figs 18a-d (ㅇ).

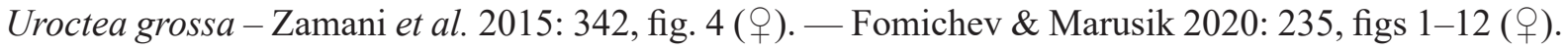
Uroctea durandi - Roewer 1955: 752 (misidentification).

Uroctea limbata - Denis 1958: 112 (misidentification, tentatively assigned to U. grossa).

\section{Emended diagnosis}

Uroctea grossa is closest to U. thaleri Rheims, Santos \& van Harten, 2007 and U. gambronica sp. nov., but differs from them and from other species of Uroctea by its larger size, its broad, V-shaped MAb2 making a sharp angle (also present in U. gambronica sp. nov.) and having a wide, fan-shaped terminal section (also present in $U$. thaleri, cf. Fig. 7A-G), by its gently curved MAb1, its relatively long, stout, curved TL (Fig. 7C, also present in U. thaleri), its short and stout $\mathrm{Bd}$ and a $\mathrm{Cd}$ that is coiled over $360^{\circ}$ and directed outwards anteriorly (vs uncoiled in U. limbata (C.L. Koch, 1843) and inwardly bent in U. thaleri; cf. Fig. 9B, Rheims et al. 2007: fig. 8 and Baum 1972: fig. 9).

\section{Material examined}

\section{Holotype}

AFGHANISTAN • + ; Kandahar Province, "Kouh Dana Ouat (bei Spin Boldaq an der Grenze von Pakistan)" [Kouh Dana Ouat (near Spin Boldaq on the Pakistan border)]; 9 May 1958; K. Lindberg leg.; "unter Steinen" [under stones]; GNM-A497.

\section{Other material}

AFGHANISTAN • 1 $\hat{\jmath}$ (only palp); Parwan Province, near Gulbahar, Rig-Revan, outside cave; 26 Jul. 1957; K. Lindberg leg.; misidentified as U. limbata; SMF-13231.

IRAN • 1 ^ิ, 5 우, 3 juvs; Fars Province, 50 km NNE of Shiraz, Bamoo Res.; $29^{\circ} 45^{\prime}$ N, $52^{\circ} 45^{\prime}$ E; 18-28 May 2000; Y.M. Marusik leg.; ZMMU • 1 o; Fars Province, Barm-e-peere-Ghaibi; 29 May 2000; Y.M. Marusik and K. Elmi leg.; ZMMU • 2 क; Fars Province, Firouzabad; $28^{\circ} 52^{\prime}$ N, 52 $2^{\circ} 32^{\prime}$ E; 6 Jun. 1974; A. Senglet leg.; MHNG • 1 juv.; Kerman Province, Qualeh-e-Asghard; F. Starmühlner leg.; misidentified as U. durandi; SMF • 1 ò, 1 o ; Mazandaran Province, Amol County, Larijan; 3552'54" N, $52^{\circ} 10^{\prime} 12^{\prime \prime}$ E; Jun. 2014; A. Zamani leg.; MHNG • 1 ô, 1 q; Sistan and Baluchistan Province, Khash, surroundings of Taftan volcano; $28^{\circ} 36^{\prime}$ N, 61 ${ }^{\circ} 07^{\prime}$ E; May 2018; A. Zamani leg.; MHNG • 1 sub ; South Khorasan Province, $40 \mathrm{~km}$ N of Naybandan; J. Garzoni leg.; MHNG • 1 ô, 3 q $ᄋ$; Tehran Province, $80 \mathrm{~km}$ E of Tehran, Damavand area, Aroo Vil.; $35^{\circ} 40^{\prime} \mathrm{N}, 52^{\circ} 27^{\prime}$ E; 15 Jun. 2000; Y.M. Marusik and F. Mozaffarian leg.; ZMMU • 1 đ, 1 juv.; Tehran Province, $5 \mathrm{~km} \mathrm{~N}$ of Tehran, Tochal Mountain; 35 $53^{\prime} \mathrm{N}$, 51 ${ }^{\circ} 20^{\prime}$ E; 2000-2900 m a.s.1.; 16 Jun. 2000; Y.M. Marusik, F. Mozaffarian and R. Bahramishad leg.;

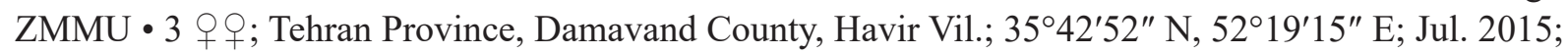
A. Zamani leg.; MHNG.

TURKMENISTAN • 1 \&; Balkan Province, SW of Kopetdagh, Damdam; 800 m a.s.1.; SMF38817. 


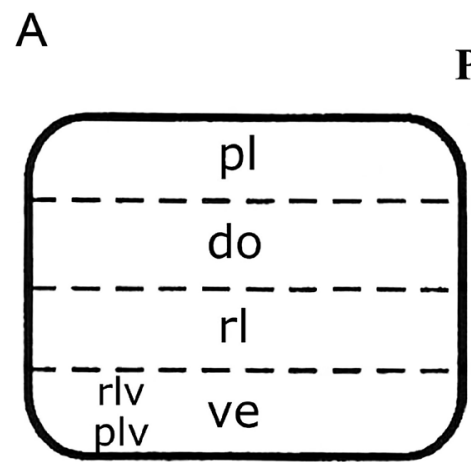

C
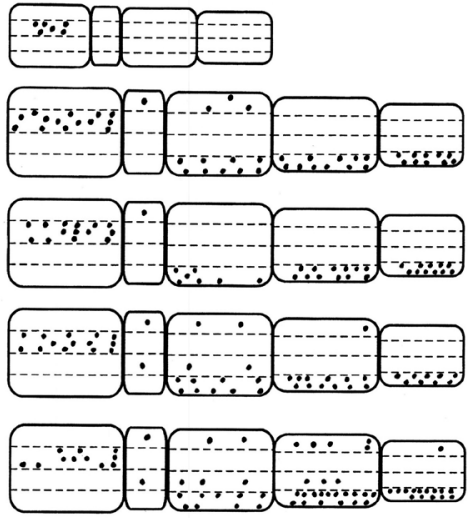

$\mathrm{F}$
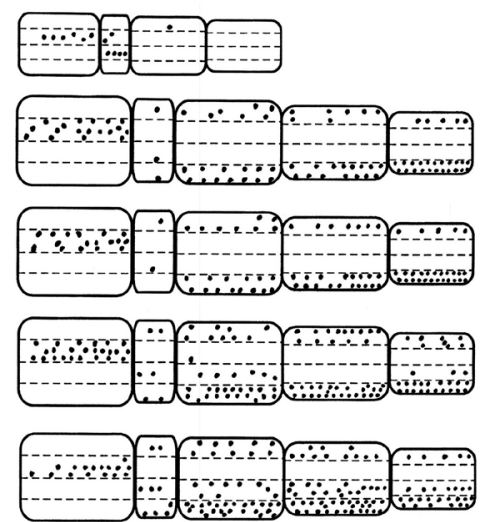
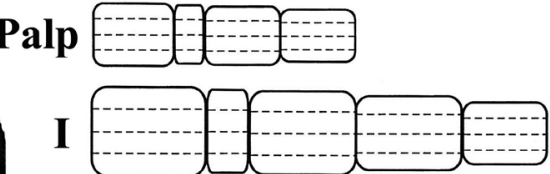

II

III

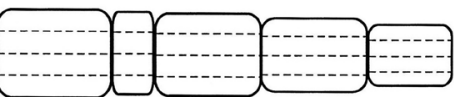

IV

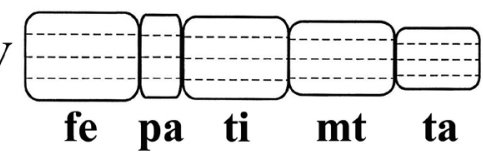

D
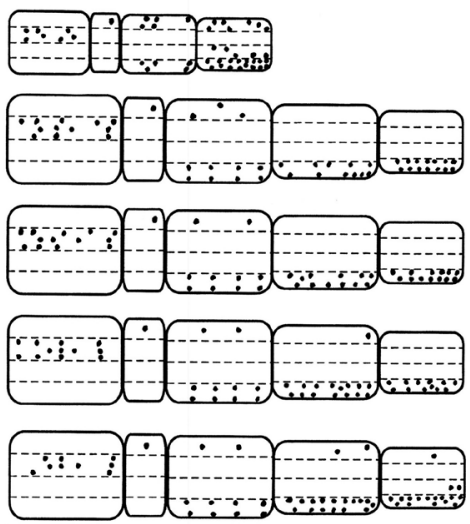

G
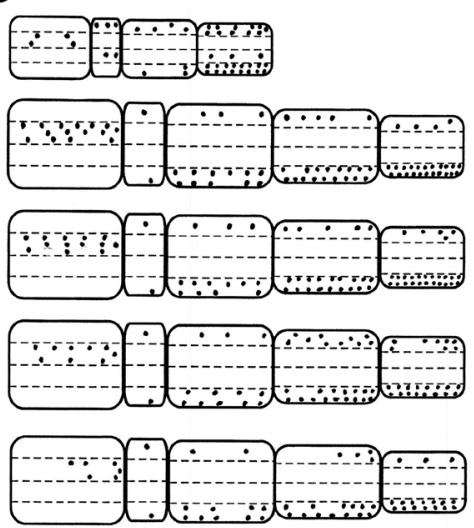
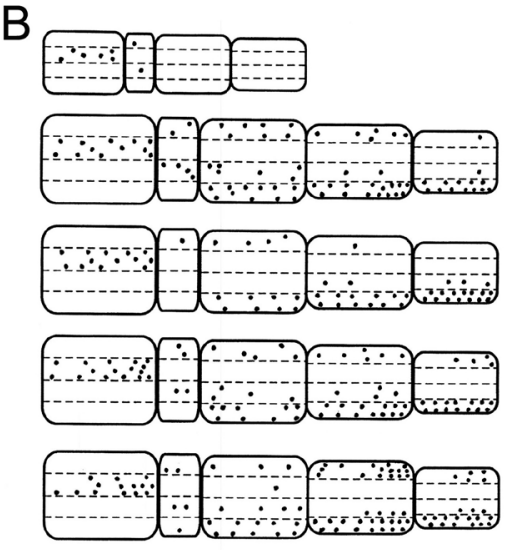

$E$
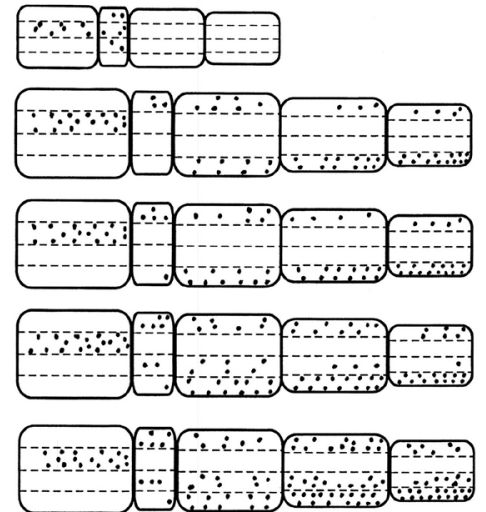

$\mathrm{H}$
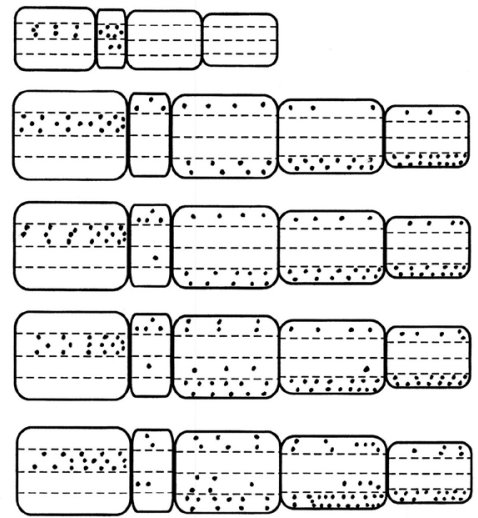

Fig. 4. Leg spination schematics. A. Legend. B. Uroctea hashemitorum Bosselaers, 1999, holotype, $\widehat{\jmath}$ (RBINS). C. Uroctea durandi (Latreille, 1809), đ̂ from Spain, Catalonia, Empordà (CJB-3992). D. Uroctea durandi, + from Spain, Catalonia, Empordà (CJB-2198). E. Uroctea thaleri Rheims, Santos \& van Harten, 2007, o from Hormozgan Province, Minab County (MHNG). F. Uroctea grossa Roewer, 1960, $\widehat{\delta}$ from Sistan and Baluchistan Province, surroundings of Taftan volcano (MHNG). G. Uroctea grossa, holotype, ㅇ (GNM-A497). H. Uroctea gambronica sp. nov., holotype, ô (NMPP6j-180/2002). 


\section{Description}

Male (measurements based on specimen from Sistan and Baluchistan Province, Iran)

Total length 9.80. Carapace broadly oval, yellowish brown with thin grey margin, faint black radial pattern and dark median band from eye region to fovea. Carapace length 4.00, width 5.05. Fovea deep triangular pit, situated 2.15 from front, length 0.30 , width 0.35 . Eyes surrounded by black pigment. AER 1.03, PER 1.00. AME larger than ALE, separated by slightly less than AME diameter. PLE similar in size to ALE, PME smaller, separated by four times their own diameter $(=0.5)$. PME and PLE touching. MOQ anterior width 0.65 , posterior width 0.75 , depth 0.45 . Clypeus 0.60 . No chilum. Chelicerae long and thin, parallel-sided, yellowish brown, length 1.35 , width 0.25 , no teeth. Sternum yellow with orange-brown border, smooth, heart-shaped. Sternum length 2.50, width 2.45. Labium free, subtriangular, length 0.60 , width 0.65 . Endites subrectangular, no serrula, no apical hair tuft. PSP long and narrow, parallel-sided, fused with sternum. Abdomen dorsally either entirely black with concentric pattern of yellowish wrinkles or bearing longitudinal oval central black mark surrounded by broad yellow zone and thin black border (Fig. 6D). Three pairs of orange-brown sigilla are present on dorsal side of abdomen. ALS subcylindrical with short apical segment. PMS small, conical. PLS with long and curved apical segment. Colulus large and covered in stiff setae. Legs greyish brown with orange brown

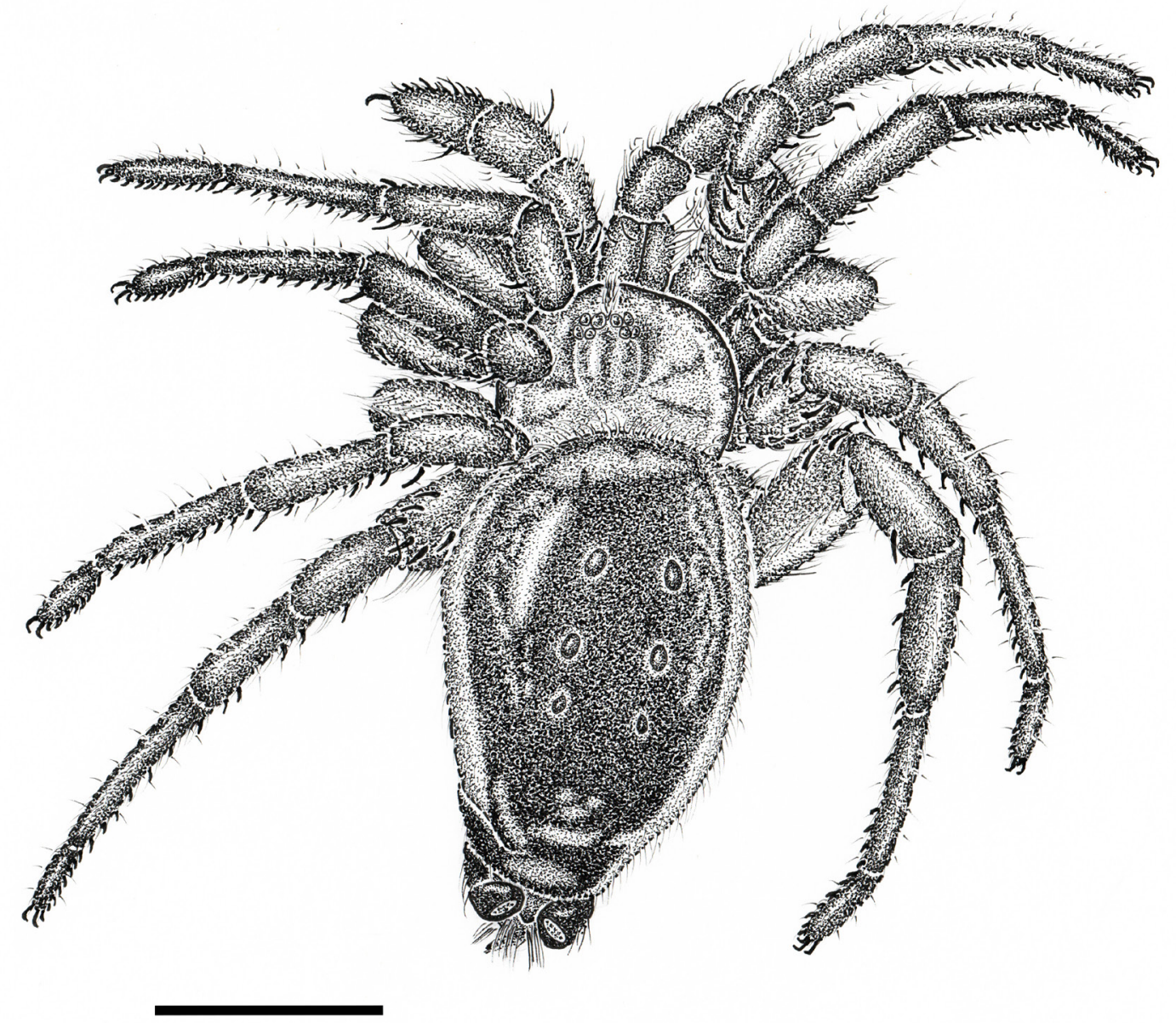

Fig. 5. Uroctea grossa Roewer, 1960, holotype, $q$ (GNM-A497); dorsal habitus. Scale bar $=4 \mathrm{~mm}$. 
$\mathrm{mt}$ and ta. Patellar indentation narrow, one third of length of pa. Tarsus IV straight. Three tarsal claws, two large ones with fine teeth. No tenent hairs. Leg formula: 4321. For leg spination see Fig. 4F.

Leg measurements:

\begin{tabular}{lcccccc}
\hline & fe & pa & ti & mt & ta & Total \\
\hline I & 5.00 & 1.75 & 3.75 & 4.00 & 2.10 & 16.60 \\
II & 5.00 & 1.75 & 3.90 & 4.25 & 1.75 & 16.65 \\
III & 4.75 & 1.75 & 3.80 & 4.75 & 1.75 & 16.80 \\
IV & 4.75 & 2.50 & 3.50 & 4.50 & 1.75 & 17.00 \\
\hline
\end{tabular}

Palp as illustrated in Fig. 7A-C, with short, pointed and curved E connected to narrow, membranous and spoon-shaped fC, long and thin, gently curved and hooked MAb1, large, sharply angled, V-shaped MAb2 with fan-shaped tip ending in three blunt terminal lobes and with large, blunt and slightly curved TL.

Female (measurements based on holotype, GNM)

Total length 13.15. Carapace broadly oval, yellowish brown, margin mottled with black (Fig. 5). Carapace length 4.15, width 5.35. Fovea deep oval pit, situated 2.35 from front, length 0.20 , width 0.35 . Eyes faintly ringed with black. AER 1.13, PER 1.15. AME larger than ALE, separated by slightly less than AME diameter. PLE similar in size to ALE, PME smaller, separated by 2.5 times their own diameter. Median and lateral eyes touching in both eye rows. MOQ anterior width 0.70 , posterior width 0.80 , depth 0.50. Clypeus 0.90. No chilum. Chelicerae long and thin, parallel-sided, yellowish brown, length 1.65 , width 0.45 , no teeth. Sternum light yellow brown with dark reddish brown border, smooth, heart-shaped. Sternum length 2.60, width 2.85. Labium free, subtriangular, length 0.70 , width 0.85 . Endites subrectangular, no serrula, no apical hair tuft. PSP long and narrow, parallel-sided, fused with sternum. Abdomen of holotype dorsally dark grey with light yellow border and thin, dark grey silky hairs (Fig. 5). Three pairs of orange-brown sigilla present on dorsal side of abdomen. ALS subcylindrical with short apical segment. PMS small, conical. PLS with long and curved apical segment. Colulus large and covered in stiff setae. Legs reddish brown, mottled with grey. Coxa I with flattened, very pale rh, length 0.20, width 0.13. Patellar indentation narrow, one third of length of pa. Tarsus IV straight. Three tarsal claws, two large ones with fine teeth. No tenent hairs. Leg formula: 4321. For leg spination see Fig. 4G.

Leg measurements:

\begin{tabular}{lcccccc}
\hline & $\mathbf{f e}$ & $\mathbf{p a}$ & $\mathbf{t i}$ & $\mathbf{m t}$ & $\mathbf{t a}$ & Total \\
\hline I & 4.10 & 1.25 & 3.10 & 3.55 & 1.85 & 13.85 \\
II & 4.50 & 1.50 & 3.50 & 3.75 & 1.90 & 15.15 \\
III & 4.50 & 1.50 & 3.50 & 4.25 & 1.80 & 15.55 \\
IV & 5.10 & 1.90 & 3.50 & 4.25 & 1.90 & 16.65 \\
\hline
\end{tabular}

Epigyne and vulva as in Figs 8-9, somewhat variable, simple, with numerous sclerotized arcs in anterior half and in posterior half with oval Co connected to Cd (Figs 8A-D). Vulva (Figs 9A-D) with long, stout $\mathrm{Cd}$ curved over $360^{\circ}$ and terminally directed outwards, and with thin, long, wavy $\mathrm{Fd}$ that are terminally recurved and connected to subtriangular sclerite (Fig. 9C-D) that tends to detach in some vulva preparations (Fig. 9). St small and sclerotized, connected to short and blunt Bd and adjacent to large, thin-walled bursae.

\section{Distribution}

Iran, Afghanistan, Tajikistan (World Spider Catalog 2020), Turkmenistan (this paper). 


\section{Records in Iran}

Kerman (Roewer 1955), North Khorasan, Razavi Khorasan (Zamani et al. 2015), Fars, Mazandaran, Sistan and Baluchistan, South Khorasan, and Tehran (this paper) Provinces.

\section{Records in Afghanistan}

Balkh, Parwan and Kandahar Provinces (Denis 1958; Roewer 1960; this paper).
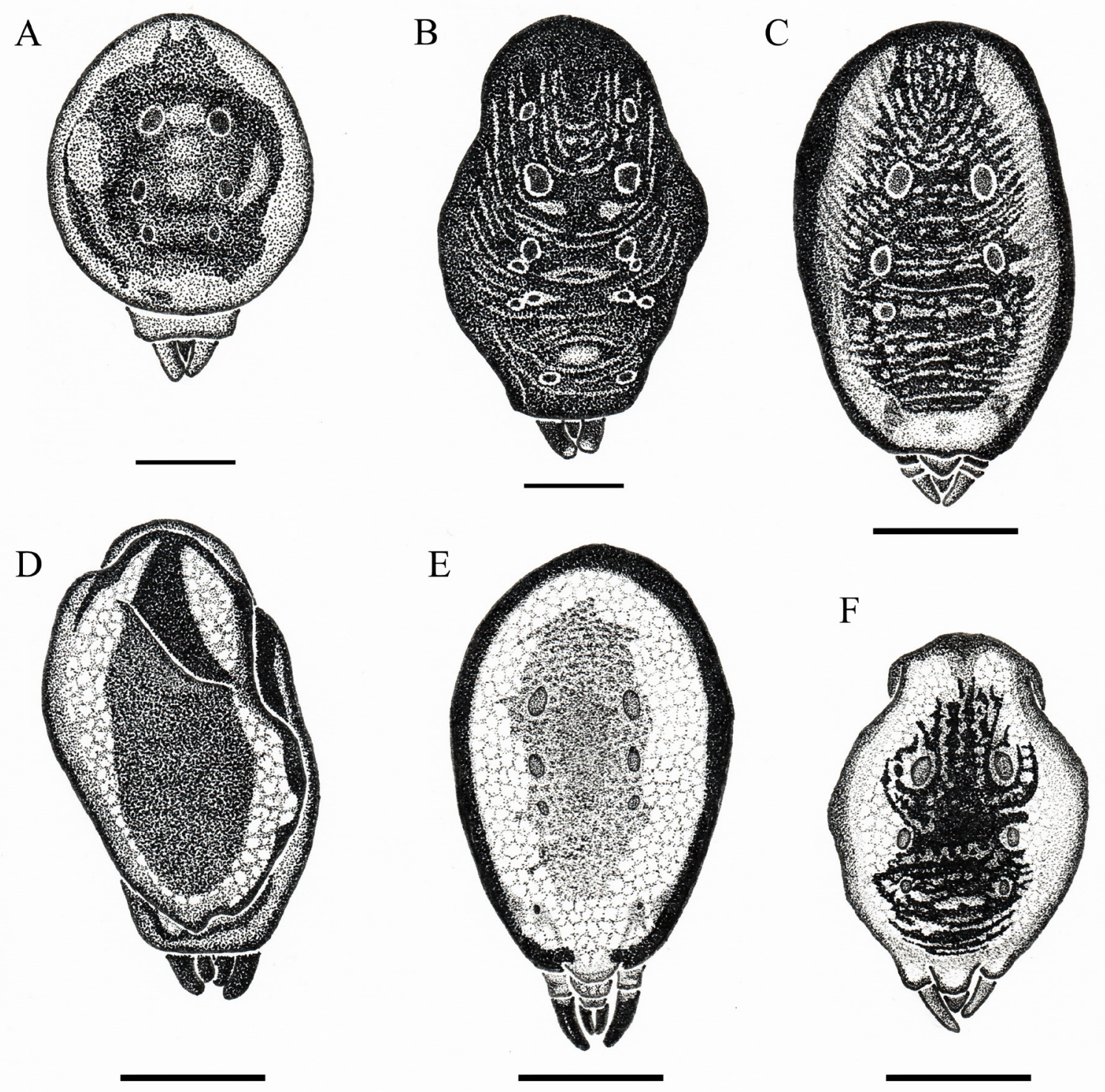

Fig. 6. Abdominal patterns, dorsal views. A-D. Uroctea grossa Roewer, 1960. A-B. $q q$ from Iran, Damavand County, Havir village (MHNG). C. $\&$ from Mazandaran Province, Larijan (MHNG).

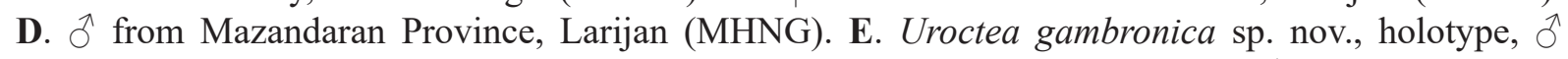
(NMP-P6j-180/2002). F. Uroctea thaleri Rheims, Santos \& van Harten, 2007, §ิ from Hormozgan Province, Minab County (MHNG). Scale bars $=2 \mathrm{~mm}$. 
A

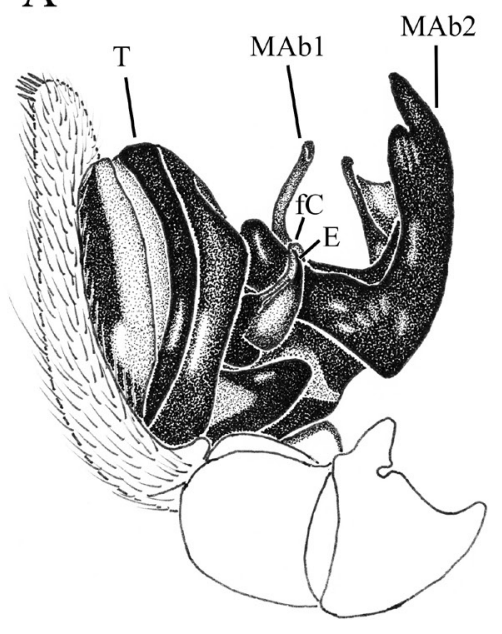

$\mathrm{D}$

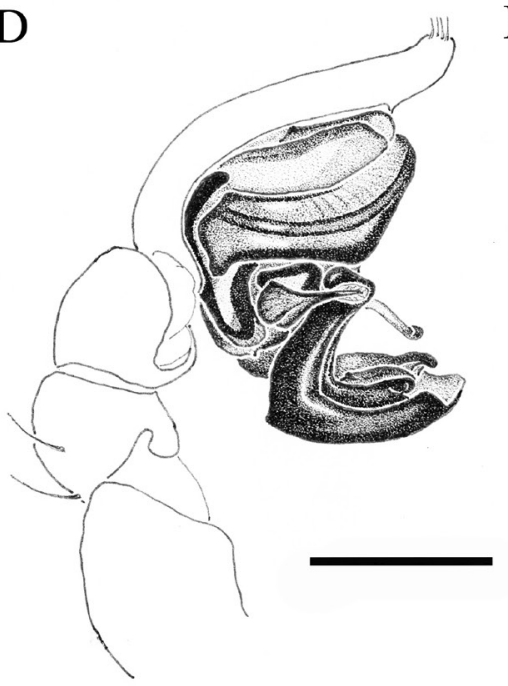

B

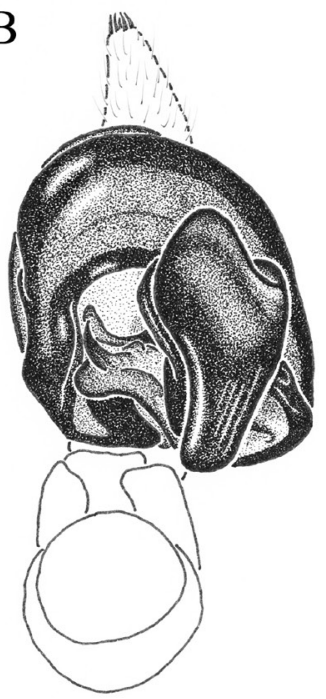

$\mathrm{E}$

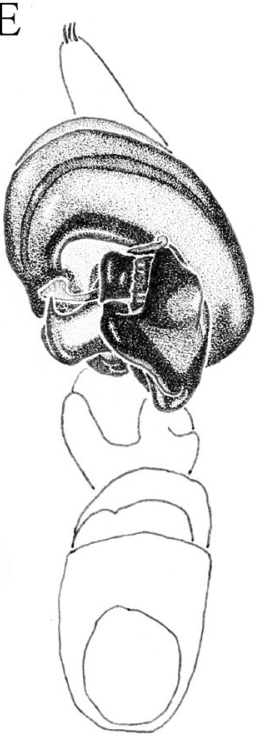

$\mathrm{C}$

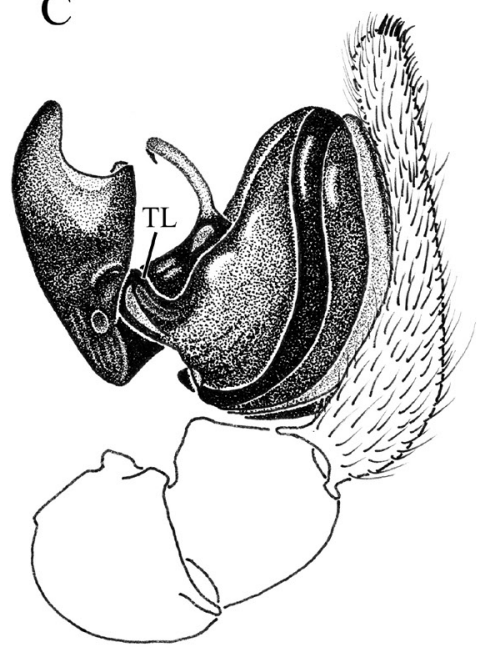

$\mathrm{F}$

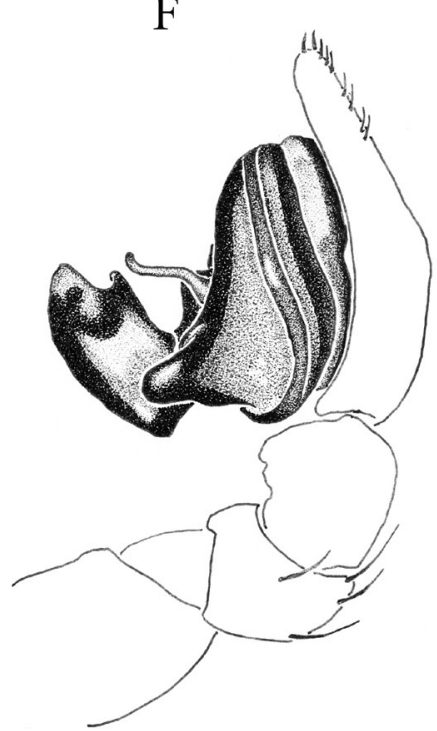

G

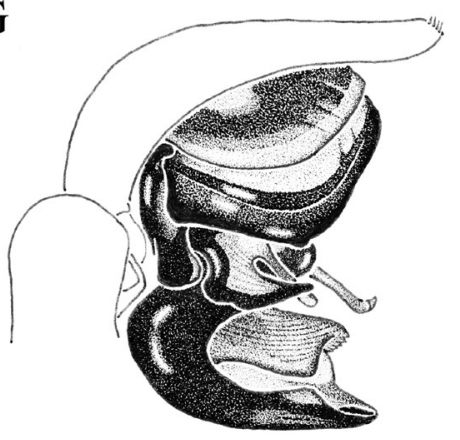

Fig. 7. Left male palps. A-C. Uroctea grossa Roewer, 1960, ô from Sistan and Baluchistan Province, surroundings of Taftan volcano (MHNG). D-F. Uroctea gambronica sp. nov., holotype, $\widehat{\partial}$ (NMPP6j-180/2002). G. Uroctea thaleri Rheims, Santos \& van Harten, 2007, ô from Hormozgan Province, Minab County (MHNG). A, D, G = prolateral view; B, E = ventral view; C, F = retrolateral view. Scale bars $=1 \mathrm{~mm}$. 


\section{Records in Turkmenistan}

Balkan Province (this paper) (Fig. 2).

Uroctea gambronica sp. nov. urn:1sid:zoobank.org:act:A8E3360D-A2B8-4E0B-B745-8AABB0D8D7F5

Figs 4H, 6E, 7D-F

Uroctea limbata - Zamani et al. 2017b: 60 (misidentification).

\section{Diagnosis}

Uroctea gambronica sp. nov. is closest to U. grossa and U. thaleri. It differs from both species by its short, straight, subconical TL of the male palp (vs long, curved and subcylindrical), the basal part of its MAb1 making a $135^{\circ}$ hook (Fig. $7 \mathrm{~F}$, vs gently curved in U. grossa and straight in U. thaleri), its smaller, subrectangular terminal section of MAb2 (vs large and fan-shaped), and its sharply toothed retrolateral lobe of MAb2 (vs bluntly toothed). It further differs from $U$. grossa by its smaller size and its lower number of ti spines (Fig. 4H vs Fig. 4F). It also differs from $U$. thaleri by its sharply angled MAb2 (vs smoothly bent, Fig. 7D vs Fig. 7G).
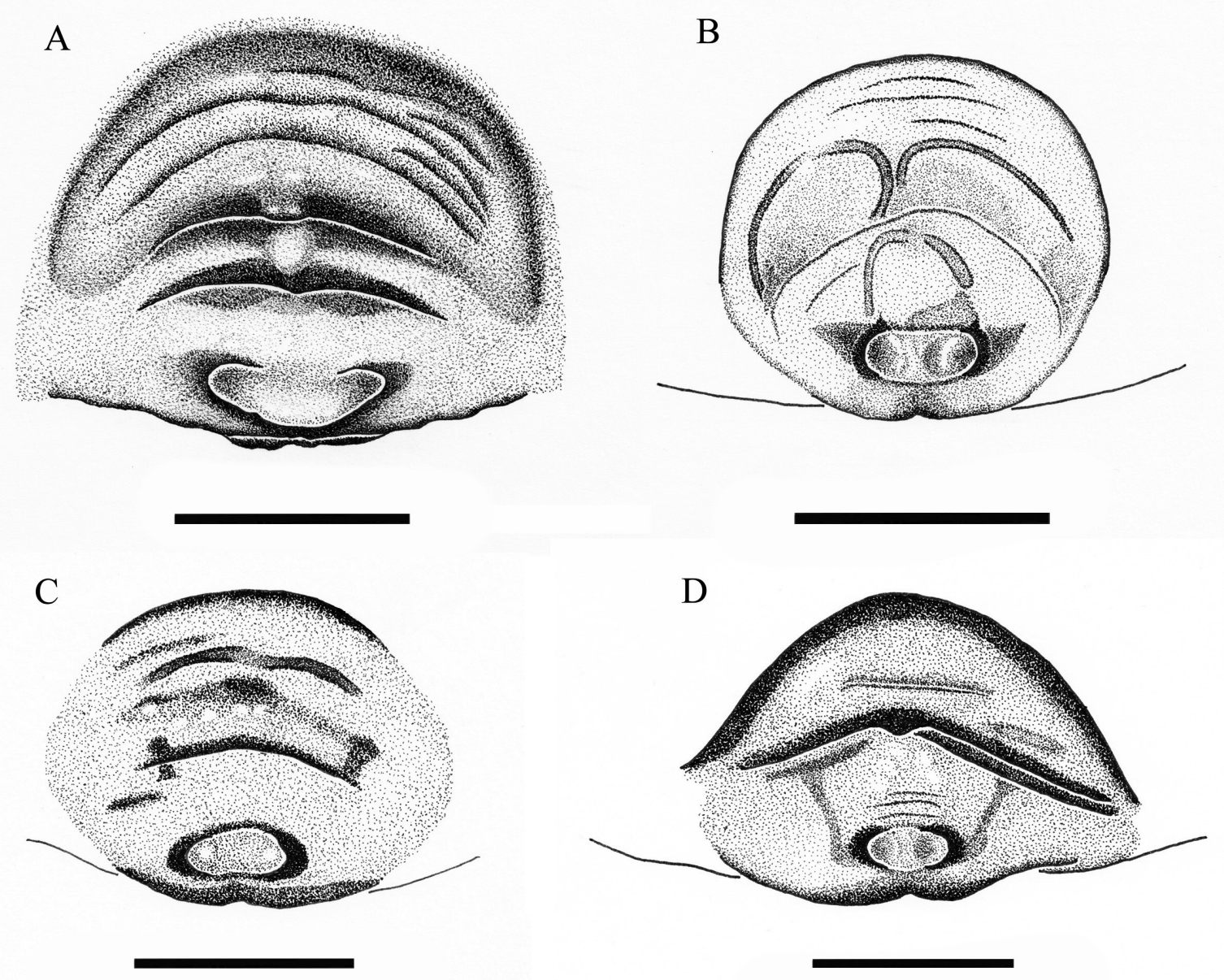

Fig. 8. Epigynes of Uroctea grossa Roewer, 1960; ventral view. A. Holotype, o (GNM-A497). B. $q$ from Mazandaran Province, Larijan (MHNG). C. $q$ from Sistan and Baluchistan Province, surroundings of Taftan volcano (MHNG). D. . from Turkmenistan (SMF38817). Scale bars $=0.5 \mathrm{~mm}$. 


\section{Etymology}

The new species is named after Gambron, the former English traders' name for Bandar Abbas, the type locality of the species.

\section{Type material}

\section{Holotype}

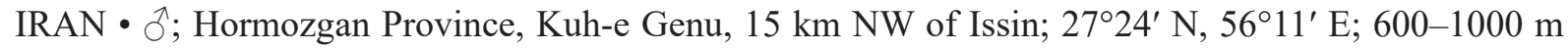
a.s.1.; Apr. 1977; B. Pražan leg.; NMP-P6j-180/2002.

\section{Description}

\section{Male}

Total length 8.85. Carapace broadly oval, yellowish brown, somewhat mottled with grey, with faint black radiae and grey reticulate pattern near border. Carapace length 3.50, width 4.05. Fovea deep triangular pit, situated 1.70 from front, length 0.35 , width 0.25 . Eyes surrounded by black pigment. AER 0.90, PER 0.88. AME larger than ALE, separated by half of AME diameter. PLE similar in size to ALE, PME smaller, separated by three times their own diameter. PME and PLE touching. MOQ anterior width 0.50 , posterior width 0.70 , depth 0.40 . Clypeus 0.65 . No chilum. Chelicerae long and thin, parallelsided, yellowish brown, length 1.15 , width 0.20 , no teeth. Sternum yellow with light brown border, smooth, heart-shaped. Sternum length 2.20, width 2.05. Labium free, subtriangular, length 0.45 , width 0.55. Endites subrectangular, no serrula, no apical hair tuft. PSP long and narrow, parallel-sided, fused with sternum. Abdomen whitish with narrow black border and central, oval, olive green patch with three pairs of olive brown sigilla (Fig. 6E). ALS light brown, blunt and conical, with short apical segment. PMS small, conical. PLS grey, with long and curved apical segment. Colulus large and covered in stiff setae. Legs yellow brown with orange brown $\mathrm{mt}$ and ta. Patellar indentation narrow, one third of length of pa. Tarsus IV straight. Three tarsal claws, two large ones with fine teeth. No tenent hairs. Leg formula: 4321. For leg spination see Fig. 4H.

Leg measurements:

\begin{tabular}{lcccccc}
\hline & $\mathbf{f e}$ & $\mathbf{p a}$ & $\mathbf{t i}$ & $\mathbf{m t}$ & $\mathbf{t a}$ & Total \\
\hline I & 4.10 & 1.50 & 3.20 & 3.60 & 2.00 & 14.40 \\
II & 4.00 & 1.50 & 3.50 & 3.80 & 1.75 & 14.55 \\
III & 4.15 & 1.50 & 3.35 & 4.25 & 1.75 & 15.00 \\
IV & 4.30 & 1.85 & 3.00 & 4.25 & 1.85 & 15.25 \\
\hline
\end{tabular}

Male palp as in Fig. 7D-F, with short, pointed and curved E connected to membranous, scoop-shaped fC, with long and thin, bent and hooked MAb1, with large, sharply angled, V-shaped MAb2 with relatively short, subrectangular scoop-shaped tip ending in two blunt and one toothed terminal lobe and broad, straight, subconical, blunt TL.

\section{Female}

Unknown.

\section{Distribution}

Currently known only from the type locality in Hormozgan Province, southern Iran (Fig. 2).

Uroctea thaleri Rheims, Santos \& van Harten, 2007

Figs 3D, 4E, 6F, 7G

Uroctea sp. indet. a. - Baum 1972: 113, figs 11-13 (ㅇ, per Rheims et al. 2007: 67).

Uroctea limbata - Zamani 2015: 14. — Sadeghi et al. 2016: 6 (misidentifications). 


\section{Material examined}

IRAN • 1 ô, 2 juv.; Fars Province, Shiraz; 1990; K. Elmi leg.; ZMMU • 1 ơ; Hormozgan Province, Minab County; Feb. 2018; A. Zamani leg.; MHNG • 1 đ̇; Ilam Province, Dehloran, Zarrinabad District;

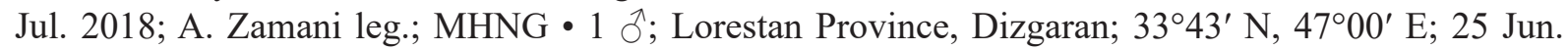

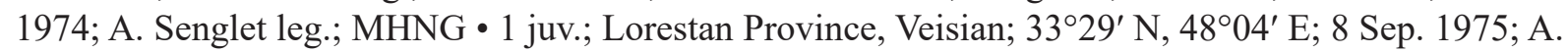

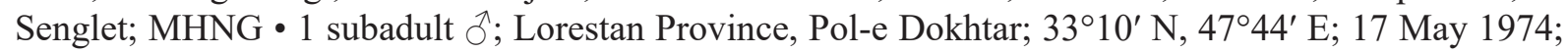
A. Senglet leg.; MHNG • 1 q; Mazandaran Province, Ghaemshahr, rice fields; Sep. 2005; H. Ghahari leg.; ZMMU.

\section{Distribution}

Turkey, Israel, Iran, Yemen, India (World Spider Catalog 2020).

A

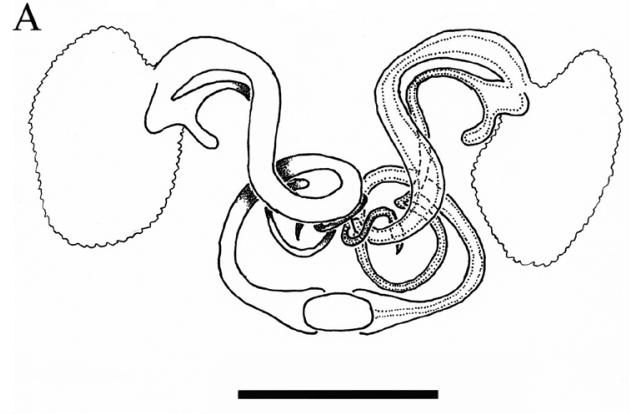

$\mathrm{C}$

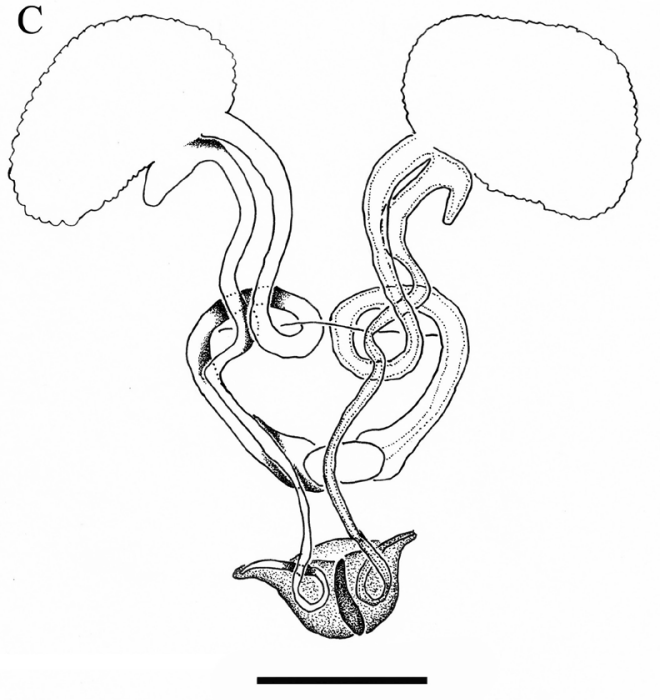

B

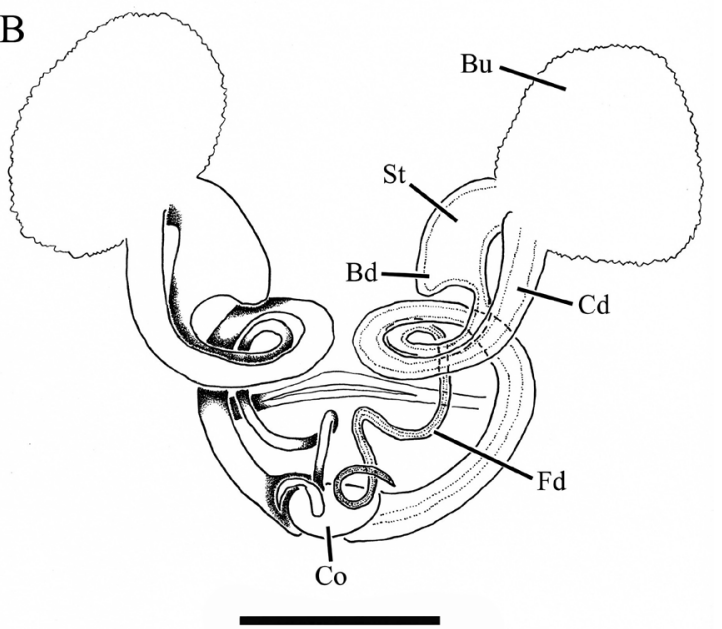

D

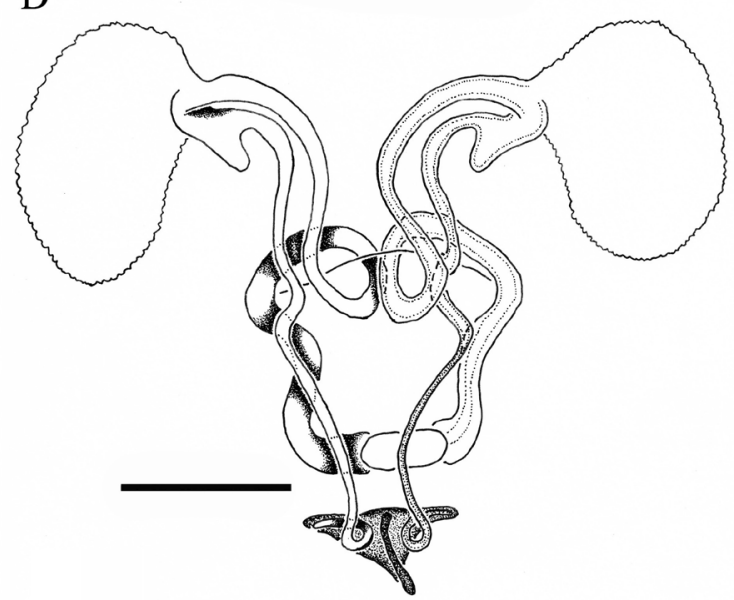

Fig. 9. Vulvae of Uroctea grossa Roewer, 1960; dorsal view. A. $q$ from Mazandaran Province, Larijan (MHNG). B. Holotype, $q$ (GNM-A497). C. $q$ from Turkmenistan (SMF38817). D. $q$ from Sistan and Baluchistan Province, surroundings of Taftan volcano (MHNG). Scale bars $=0.5 \mathrm{~mm}$. 


\section{Records in Iran}

Ilam, Khuzestan, Razavi Khorasan, Semnan (Baum 1972; Hosseini et al. 2014; Zamani 2015; Namaghi et al. 2016; Zamani \& Mozaffarian 2017), Fars, Hormozgan, Lorestan and Mazandaran (this paper) Provinces (Fig. 2).

\section{Discussion}

The male palp and vulva of Oecobiidae are notoriously complex. For the male palps, Shear (1970), Baum (1972) and Bosselaers (1999) used the terminology of Comstock (1910), without due consideration of homology, in spite of the fact that Comstock's terminology was mainly based on the palpal structure of Linyphiidae Blackwall, 1859 and Araneidae Clerck, 1757. Coddington (1990) highlighted this problem and proposed a palpal terminology specifically applicable to Oecobiidae and Hersiliidae Thorell, 1870. Coddington calls Baum's (1972) "radix" the "oecobiid tegular lobe". This structure is called "tegular lobe" by Rheims et al. (2007) and Kunt et al. (2009). Baum's "terminal apophysis" and "functional conductor" are named "oecobiid terminal apophysis" and "oecobiid embolic apophysis", respectively, by Coddington. Baum's (1972: fig. 62) "median apophysis" is situated proximally to the tegulum and, as a result, is certainly not a median apophysis sensu Comstock (1910: 172, 179), which is a sclerite "Arising within the distal margin of the tegulum", and "joined by a flexible articulation to the tegulum". Coddington (1990: fig. 5) completely misinterprets Baum's median apophysis and therefore has no useful name for it. What Coddington calls "median apophysis" is in fact a basal lobe of the tegulum. As a result of this confusion, Yang et al. (2019: 137) could not "match the median apophysis of Coddington (1990) and Bosselaers (1999) with male palpal structures of Uroctea species here described." The "median apophysis" of Bosselaers (1999) is basically Baum's median apophysis. Yang et al. (2019) developed their own terminology, considering Baum's terminal and subterminal apophyses as one multibranched median apophysis. We consider this interpretation justified and applied it here. Yang's et al. (2019) use of the term conductor, on the other hand, seems unjustified, as this structure is not a separate sclerite in Uroctea, but an appendage of the embolus. Therefore, we used the term "functional conductor". For Baum's "radix", we followed Rheims et al. (2007) and Kunt et al. (2009) in calling it "tegular lobe". For the sake of clarity, the palpal terminology used by different authors is summarized in Table 1.

The vulvar terminology of Oecobiidae has also proven to be problematic. Yang et al. (2019) rightly argue that Baum's $(1972,1980)$ transparent, poorly sclerotized "receptacula" are in fact bursae, while her "B1", interpreted by Baum as the globular, sclerotized first stretch of the fertilization duct, are the actual spermathecae. Yang et al. (2019) do not mention Baum's "blind endender Anhang (A)", because it is not present in the Uroctea durandi (Latreille, 1809) species group (Benoit 1966: 192). We called this structure "blind ending duct", following Rheims et al. (2007). Apart from this, we applied Yang's et al. (2019) vulvar terminology in this paper.

It is noteworthy that seven species of Uroctea (U. gambronica sp. nov., U. grossa, U. hashemitorum Bosselaers, 1999, U. limbata, U. paivani (Blackwall, 1868), U. sudanensis Benoit, 1966 and U. thaleri) differ from Uroctea durandi, the type species of the genus, by the considerably larger number of prolateral spines on tarsus, metatarsus and tibia ((1)3-9(16) vs 0-3(5), Fig. 4), by the very large, scoopshaped "branch 2" of the median apophysis (vs medium-sized, flat, pointed and subtriangular), the absence of a MAb3 (vs present), the presence of a conspicuous tegular lobe in the male palp (vs very small to absent), and the presence of a blind ending duct in the vulva (vs absent). This group of species might belong to a distinct, currently undescribed genus; this matter shall be investigated in future using integrative taxonomic methods.

Considering the results of this paper, there are now nine species of Oecobiidae known from Iran, and three are known from Afghanistan and Turkmenistan. Nevertheless, the arachnological research in the 
Table 1. Palpal terminology related to Oecobiidae in six publications.

\begin{tabular}{cccccc}
\hline $\begin{array}{c}\text { Comstock } \\
(\mathbf{1 9 1 0})\end{array}$ & Shear (1970) & Baum (1972) & $\begin{array}{c}\text { Coddington } \\
(\mathbf{1 9 9 0 )}\end{array}$ & $\begin{array}{c}\text { Yang } \text { et al. } \\
\mathbf{( 2 0 1 9 )}\end{array}$ & $\begin{array}{c}\text { Present } \\
\text { paper }\end{array}$ \\
\hline$?$ & $\mathrm{~T}$ & $\mathrm{MA}$ & $?$ & $?$ & - \\
$\mathrm{T}$ & $\mathrm{Ra}$ & $\mathrm{T}$ & $\mathrm{T}$ & $\mathrm{T}$ & $\mathrm{T}$ \\
$?$ & $\mathrm{~S}$ & $\mathrm{Ra}$ & OTL-1 & - & $\mathrm{TL}$ \\
$?$ & $\mathrm{~S}$ & $\mathrm{RaA}$ & OTL-1 & - & $\mathrm{TL}$ \\
- & - & STA-1 & - & MAb1 & MAb1 \\
- & - & STA-2 & - & MAb3 & MAb3 \\
- & $\mathrm{C}$ & $\mathrm{TA}$ & OTA & MAb2 & MAb2 \\
$\mathrm{C}$ & $\mathrm{C}$ & fC & OEA & $\mathrm{C}$ & $\mathrm{fC}$ \\
$\mathrm{E}$ & $\mathrm{E}$ & $\mathrm{E}$ & $\mathrm{E}$ & $\mathrm{E}$ & $\mathrm{E}$ \\
$?$ & $\mathrm{~S}$ & $\mathrm{~S}$ & - & - & - \\
\hline
\end{tabular}

region is still in the discovery phase, and new sampling efforts, especially in remote and geographically diverse areas (e.g., Zagros, Kopet Dagh and Hindu Kush mountain ranges, Sahand-Bazman Volcanic and Plutonic Belt), could yield more undescribed species and new records.

\section{Acknowledgments}

We are grateful toward Peter J. Schwendinger (MHNG), Julia Altmann and Peter Jäger (SMF), Charlotte Jonsson (GNM) and Petr Dolejš (NMP) for sending us the material deposited in the collections, and Yuri M. Marusik for providing us with his collected material from Iran.

\section{References}

Baum S. 1972. Zum "Cribellaten-Problem": Die Genitalstrukturen der Oecobiinae und Urocteinae (Arach.: Aran.: Oecobiidae). Abhandlungen und Verhandlungen des Naturwissenschaftlichen Vereins in Hamburg (N.F.) 16: 101-153.

Baum S. 1980. Taxonomie und Genitalstrukturen weiterer Arten der Genera Oecobius und Uroctea (Arach.: Araneae: Oecobiidae). Verhandlungen des Naturwissenschaftlichen Vereins in Hamburg 23: 339-355.

Benoit P.L.G. 1966. Contribution à la connaissance des Urocteidae africains (Aranea-Labidogn.). Bulletin \& Annales de la Société entomologique de Belgique 102: 191-195.

Bosselaers J. 1999. A new Uroctea from the Jordan desert (Araneae: Oecobiidae). Phegea 27: 103-113.

Bosselaers J. \& Jocqué R. 2002. Studies in Corinnidae: cladistic analysis of 38 corinnid and liocranid genera, and transfer of Phrurolithinae. Zoologica Scripta 31: 241-270.

https://doi.org/10.1046/j.1463-6409.2002.00080.x

Boukan A., Rajabi R., Oshaghi M.A., Rafinejad J. \& Seyyar O. 2018. A contribution to the knowledge of the spider fauna of Iran (Araneae: Oecobiidae). Serket 16 (1): 23-26.

Coddington J.A. 1990. Ontogeny and homology in the male palpus of orb-weaving spiders and their relatives, with comments on phylogeny (Araneoclada: Araneoidea, Deinopoidea). Smithsonian Contributions to Zoology 496: 1-52. https://doi.org/10.5479/si.00810282.496

Comstock J.H. 1910. The palpi of male spiders. Annals of the Entomological Society of America 3 (3): 161-185. https://doi.org/10.1093/aesa/3.3.161 
Demir H., Seyyar O. \& Aktaş M. 2009. Contributions to the knowledge of the genus Oecobius Lucas, 1846 from Turkey (Araneae: Oecobiidae). Turkish Journal of Zoology 33: 457-462.

https://doi.org/10.3906/zoo-0806-16

Denis J. 1958. Araignées (Araneidea) de l'Afghanistan. I. Videnskabelige Meddelelser fra Dansk Naturhistorisk Forening i Kjøbenhavn 120: 81-120.

Dürer A. 1525. Underweysung der Messung mit den Zirckel, und Richtscheyt, in linien, ebnen und gantzen Corporen. Hieronymus Andreas Formschneider, Nuremberg.

El-Hennawy H.K. 2016. A note on Oecobius amboseli Shear \& Benoit, 1974 (Araneae: Oecobiidae). Serket 15 (1): 68-70.

Fomichev A.A. \& Marusik Y.M. 2020. The first record of the spider subfamily Urocteinae Thorell, 1869 (Aranei: Oecobiidae) in Tajikistan. Arthropoda Selecta 29 (2): 235-238.

https://doi.org/10.15298/arthsel.29.2.08

Ghahari H. \& Marusik Y.M. 2009. New data on spider fauna of Iran (Araneae). Turkish Journal of Arachnology 2: 1-8.

Hassan A.I. 1953. The Oecobiidae of Egypt. Bulletin - Zoological Society of Egypt 11: 14-28.

Hosseini M., Mirshamsi O., Kashefi R. \& Fekrat L. 2014. A contribution to the knowledge of spiders in wheat fields of Khorasan-e-Razavi Province, Iran. Turkish Journal of Zoology 38: 437-443.

https://doi.org/10.3906/zoo-1307-16

Kullmann E. \& Zimmermann W. 1976. Beschreibung der neuen Spinnenart Oecobius afghanicus mit ergänzenden Angaben zu Oecobius putus und Oecobius annulipes (Arachnida: Araneae: Oecobiidae). Entomologica Germanica 3: 41-50.

Kunt K.B., Yağmur E.A., Danişman T., Bayram A. \& Kaya R.S. 2009. Genus Uroctea Dufour, 1820 (Araneae: Oecobiidae) in Turkey. Serket 11: 93-101.

Ledoux J.-C. \& Canard A. 1991. Initiation à l'étude systématique des araignées. J.-C. Ledoux, Aramon.

Lehtinen P.T. 1967. Classification of the cribellate spiders and some allied families, with notes on the evolution of the suborder Araneomorpha. Annales Zoologici Fennici 4: 199-468.

Marusik Y.M., Omelko M.M. \& Koponen S. 2015. Redescription of Oecobius tadzhikus Andreeva et Tyshchenko, 1969 (Aranei: Oecobiidae). Arthropoda Selecta 24 (2): 197-200.

https://doi.org/10.15298/arthsel.24.2.05

Mikhailov K.G. \& Fet V. 1994. Fauna and zoogeography of spiders (Aranei) of Turkmenistan. In: Fet V. \& Atamuradov K.I. (eds) Biogeography and Ecology of Turkmenistan: 499-524. Kluwer Academic Publisher, Netherlands.

Namaghi H.S., Safari A., Entezari E. \& Zamani A. 2016. New faunistic records of spiders (Araneae) from northeastern Iran. Zoology and Ecology 26: 18-21.

https://doi.org/10.1080/21658005.2015.1104812

Raven R. 1998. Revision of the Australian genera of the Miturgidae with a preview of their relationships. In: XIVth International Congress of Arachnology, Abstracts: 31.

Rheims C.A., Santos A.J. \& Harten A. van 2007. The spider genus Uroctea Dufour, 1820 (Araneae: Oecobiidae) in Yemen. Zootaxa 1406: 61-68.

Roewer C.F. 1955. Die Araneen der Österreichischen Iran-Expedition 1949/50. Sitzungsberichte der Österreichischen Akademie der Wissenschaften (I) 164: 751-782. 
Roewer C.F. 1960. Solifugen und Opilioniden - Araneae Orthognathae, Haplogynae und Entelegynae (Contribution à l'étude de la faune d'Afghanistan 23). Göteborgs Kungliga Vetenskaps och Vitterhets Samhälles Handlingar 8 (7): 1-53.

Sadeghi H., Ahmadi M., Zamani A. \& Jabaleh I. 2016. A study on the spider fauna of Dargaz and Kalat Counties in Razavi Khorasan Province, Iran (Arachnida: Araneae). Biharean Biologist 10 (1): 4-7.

Shear W.A. 1970. The spider family Oecobiidae in North America, Mexico, and the West Indies. Bulletin of the Museum of Comparative Zoology 140: 129-164.

Simon E. 1892. Histoire naturelle des Araignées. Tome 1. Roret, Paris. https://doi.org/10.5962/bhl.title.51973

Wunderlich J. 1995. Zu Taxonomie und Biogeographie der Arten der Gattung Oecobius Lucas 1846, mit Neubeschreibungen aus der Mediterraneis und von der Arabischen Halbinsel (Arachnida: Araneae: Oecobiidae). Beiträge zur Araneologie 4 (1994): 585-608.

World Spider Catalog. 2020. World Spider Catalog. Version 21.0. Natural History Museum Bern. Available from http://wsc.nmbe.ch [accessed 1 May 2020]. https://doi.org/10.24436/2

Yang Z.Z., Yang Z.B., Zhao Y. \& Zhang Z.S. 2019. Review of the tent-web spider genus Uroctea Dufour, 1820 in China, with descriptions of two new species (Araneae: Oecobiidae). Zootaxa 4679 (1): 126-138. https://doi.org/10.11646/zootaxa.4679.1.8

Zamani A. 2015. The spider collection (Arachnida: Araneae) of the Zoological Museum of the Iranian Research Institute of Plant Protection, with new species records for Iran. Arachnologische Mitteilungen 50: 11-18. https://doi.org/10.5431/aramit5002

Zamani A. 2016. The Field Guide of Spiders and Scorpions of Iran. Iranshenasi, Tehran. [In Persian.]

Zamani A. \& Marusik Y.M. 2018. The first report on the spider fauna (Arachnida: Araneae) of the Lut Desert, Iran. Acta Arachnologica 67 (2): 67-75. https://doi.org/10.2476/asjaa.67.67

Zamani A., Mirshamsi O., Jannesar B., Marusik Y.M. \& Esyunin S.L. 2015. New data on spider fauna of Iran (Arachnida: Araneae), Part II. Zoology and Ecology 25 (4): 339-346.

https://doi.org/10.1080/21658005.2015.1068508

Zamani A., Mirshamsi O., Kashani G.M. \& Karami L. 2018 [2017]. New data on the spider fauna of Iran (Arachnida: Araneae), Part V. Iranian Journal of Animal Biosystematics 13 (2): 183-197. https://doi.org/10.22067/ijab.v13i2.72404

Zamani A., Mirshamsi O., Marusik Y.M., Hatami M. \& Maddahi H. 2017a. The spider genus Oecobius in Iran, with description of two new species (Araneae: Oecobiidae). Oriental Insects 51 (4): 330-337. https://doi.org/10.1080/00305316.2017.1283257

Zamani A., Mirshamsi O., Dolejš P., Marusik Y.M., Esyunin S.L., Hula V. \& Ponel P. 2017b. New data on the spider fauna of Iran (Arachnida: Araneae), Part IV. Acta Arachnologica 66 (2): 55-71.

https://doi.org/10.2476/asjaa.66.55

Zamani A., Mirshamsi O., Rashidi P., Marusik Y.M., Moradmand M. \& Bolzern A. 2016. New data on the spider fauna of Iran (Arachnida: Aranei), part III. Arthropoda Selecta 25 (1): 99-114.

https://doi.org/10.15298/arthsel.25.1.10

Zamani A. \& Mozaffarian F. 2017. Further spider (Arachnida: Araneae) material deposited in the Agricultural Zoology Museum of Iran (AZMI), Iranian Research Institute of Plant Protection. Arachnologische Mitteilungen 54: 8-20. https://doi.org/10.5431/aramit5403 
Manuscript received: 4 June 2020

Manuscript accepted: 24 September 2020

Published on: 2 December 2020

Topic editor: Rudy Jocqué

Desk editor: Radka Rosenbaumová

Printed versions of all papers are also deposited in the libraries of the institutes that are members of the EJT consortium: Muséum national d'histoire naturelle, Paris, France; Meise Botanic Garden, Belgium; Royal Museum for Central Africa, Tervuren, Belgium; Royal Belgian Institute of Natural Sciences, Brussels, Belgium; Natural History Museum of Denmark, Copenhagen, Denmark; Naturalis Biodiversity Center, Leiden, the Netherlands; Museo Nacional de Ciencias Naturales-CSIC, Madrid, Spain; Real Jardín Botánico de Madrid CSIC, Spain; Zoological Research Museum Alexander Koenig, Bonn, Germany; National Museum, Prague, Czech Republic. 